\title{
Students' Online Learning Satisfaction on Learning Management System
}

\author{
Ares Albirru Amsal ${ }^{1, *}$ Meuthia $^{1}$ \\ ${ }^{1}$ Department of Management Faculty of Economics Universitas Andalas, Padang West Sumatra Indonesia \\ *Corresponding author. Email: aresalbirruamsal@eb.unand.ac.id
}

\begin{abstract}
In the Covid-19 pandemic situation, face-to-face learning had to be eliminated and replaced with online learning. To support this online learning, Andalas University encourages the use of the Learning Management System (LMS) which has been adopted from the Modular Object-Oriented Dynamic Learning Environment and is named iLearn. In this study, iLearn is used as a platform to assess the level of satisfaction in online learning. This platform allows students to access material online and also collect assignments at predetermined times. To compile this research model, we use three main factors in measuring e-learner satisfaction, namely; "Learner interface", "learning community", and "personalization" with the mediating variable "intention to use". Subjects are 274 students of the Faculty of Economics, Anadalas University who are taking Operational Management courses in 2020. The results of the structural equation modeling (SEM) analysis show that 'learner interface', and 'personalization' affect 'intention to use' which in turn affects intention to use. 'satisfaction'.
\end{abstract}

Keywords: LMS, Satisfaction, Structural equation Modelling

\section{INTRODUCTION}

Learning using a learning management system (LMS) has been widely used in universities [1] [2], including in Indonesia. LMS is software in the field of education for distributing, tracking, and managing courses via the internet. In general, there are three ways to take advantage of the LMS [3]. First, the LMS can be used as a support for face-to-face learning, where the LMS functions as a storage area for the lecture material delivered. Furthermore, LMS can be used as a means of blended learning by combining conventional learning with online methods. Third, LMS can be used for distance learning where lectures as a whole are given via the internet. The three methods can be adjusted based on the situation and the type, of course, being held [4].

Delivering material online has the potential to reduce students' level of understanding. Currently, there are several tools used to support this learning, such as Whatsapp, Zoom, Google Classrooms, and Modular Object-Oriented Dynamic Learning Environment (Moodle). In this research, we used the modified Universitas Andalas Moodle platform named iLearn. This platform allows lecturers and students to interact asynchronously. Lecturers will usually upload learning materials for one semester along with the assignments, and students will access the content periodically.

The Covid-19 pandemic has forced massive changes in people's lives and education. The application of social distancing has caused face-to-face offline classes to be eliminated and replaced with online methods. LMS, as a system specifically designed for education, is very crucial to be utilized. However, the massive use of LMS suddenly became a problem where both lecturers and students were not too comfortable using it. Students, as the majority of LMS users, need to measure their level of satisfaction in the learning process they are participating in.

The purpose of this paper is to support the effectiveness of the use of LMS in improving the quality of online learning for the Operational Management course at the Faculty of Economics, Universitas Andalas. To achieve the objective, we use 
a model offered by DeLone and McLean [6] and Wang [7] to discuss the factors that influence online learning satisfaction for students of economics faculty. The findings from this study will become a reference for online learning using iLearn for economics faculties, and evaluation for iLearn Unand providers. A good system will support students in understanding operational management learning materials.1.1. Learning Management Systems (LMS)

The LMS platform is used by lecturers or instructors to create and organize courses [8], [9]. There are many features in the LMS that allow online learning to be carried out well, such as; discussion through forums or chat, providing course content (syllabus or subject matter), creating quizzes and automatic exams, submitting assignments, surveys, and students' activity records. Among many LMSs, Moodle is the most widely used service in Indonesia both by higher education and government because it is open source. Moodle also allows users to customize the software based on user characteristics.

The potential positive impact of using LMS has made LMS spread throughout the world. In 2007, the use of LMS in 994 educational institutions in the US reached $97.5 \%$ [10]. This figure is even higher when grouped at the university level. However, the use of LMS is not always in line with student satisfaction [11]. This is because the teaching and learning process remains an important aspect because LMS is mostly used as a tool for sharing learning material [12], [13].

Research related to the effectiveness of LMS explains LMS success involving student performance, teaching design, student satisfaction, economic levels, and prevention of dropouts [14]. However, despite the massive use of LMS, the fact that students and instructors use LMS is limited for formal academic purposes [15]. Thus, exploring the determinants of LMS success is worth doing.

\subsection{LMS users' satisfaction}

Learning using LMS is an innovation in the field of education [5]. However, implementing an LMS requires a high level of IT infrastructure, and users must be ready and ready to accept the system before they can experience the benefits. Therefore, the benefits of technological innovation should be based on actual use [16], [17]. However, based on the Technology Acceptance Model (TAM) theory, 'intention to use' will affect actual use [18]. Referring to the IS Success Model by DeLone and McLean, 'intention to use' also affects 'user satisfaction' (Figure 1) [6]. Moreover, based on user satisfaction, which is the result of several factors such as content, user interface, learning community, customization, and learning performance, Wang identified four factors namely - 'learning community', 'learning community', 'content', and 'personalization' (Figure 2) [6]. Based on the IS Success Model and the e-learner satisfaction model [7], the researcher uses a research framework combining the two models. This model was also used by Chen et.al [5]. However, in their research, personalization and content are statistically the same. Therefore, in this study, we combine content and personalization into full personalization.

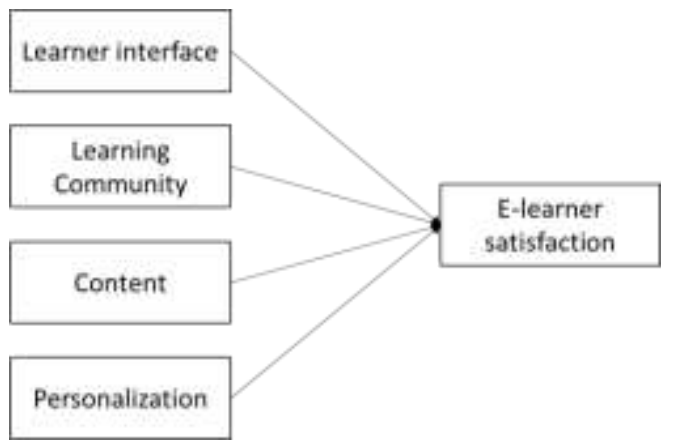

Figure 1 D\&M IS Success Model (DeLone and Mclean) [6]

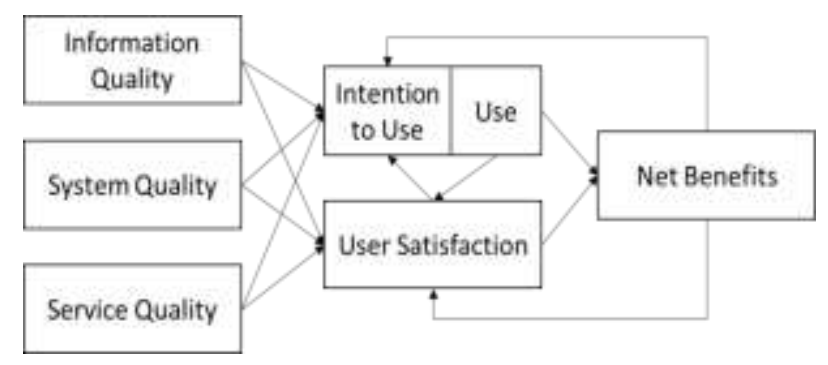

Figure 2 E-Learner satisfaction model (Wang) [7]

From the literature previously mentioned, we used the four main factors of student satisfaction and the relationship between "intention to use" and "satisfaction" of the IS Success Model to summarize a research framework that can determine the satisfaction level of students in the economics faculty. The framework is illustrated in Figure 3. Based on this framework, a four hypothesis was formed, namely:H1: The design of the LMS interface affects intention to use

$\mathrm{H} 2$ : The learning community of LMS will influence the intention to use

H3: Personalization of LMS will influence the intention to use

H4: Intention to use the LMS will influence users' satisfaction 


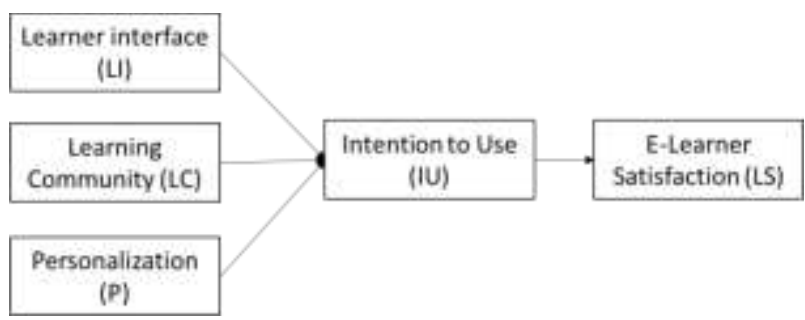

Figure 3 Research framework [5]

\section{METHODS}

\subsection{Case Operations Management}

Operations Management course, in general, is an effort to manage optimally in the use of various production factors, ranging from human resources (HR), machines, tools, raw materials, and other production factors in the process of turning them into various product or service.

The Operational Management course (EKM 209) focuses on the systematic planning, design, and operation of all processes required to produce goods and services. Operations management covers nearly all of the value-added activities of an organization, including product and process design, customer order management, production, and service. Also, operations management includes several other supporting activities such as project management, process improvement, inventory management, and material requirements planning (MRP).

This course is a compulsory subject for undergraduate students majoring in management and elective courses in accounting. After studying operational management, students are expected to be able to: 1) understand and explain the concept of Operations Management, 2) understand and analyze operational function problems, 3) be able to complete decisions related to operations management.

The subjects of this study were students taking operations management courses in 2020, where lectures were conducted online. The methodology used is a survey. Questionnaires were distributed to students online at the end of lectures after the final semester exams. From 314 respondents who filled in, the total that could be processed further was 274 .

\subsection{Instruments}

The questionnaire refers to Chen's research model [5] which combines the IS success model [6], and learner satisfaction [7]. The questionnaire was then adapted to the conditions of the Universitas Andalas Faculty of Economics student. The questionnaire consists of two parts, namely demographics and questions related to research variables such as "satisfaction", "intention to use", and LMS. Demographic information includes gender, laptop ownership, internet quality, and entry points for using e-learning. LMS-related questions include "learner interface", "learning community", "content", "personalization", "intention to use" and "e-learner satisfaction". The question is measured using a 5-point Likert scale where 1 represents strongly disagree and 5 strongly agrees. The questions are structured to cover six variables. The number of variables and questions is presented in Table 1. Questions are submitted in Indonesian after being peer-reviewed to assess the appropriateness of the context.

Table 1. Variables, questions quantity, dan references

\begin{tabular}{|l|l|l|}
\hline Constructs & Q & Reference \\
\hline Learner Interface (LI) & 5 & \multirow{2}{*}{ Wang [7] \& Chen } \\
\cline { 1 - 2 } $\begin{array}{l}\text { Learning Community } \\
\text { (LC) }\end{array}$ & 4 & \\
\cline { 1 - 2 } Personalization (P) & 8 & \\
\cline { 1 - 2 } $\begin{array}{l}\text { e- Learner Satisfaction } \\
\text { (LS) }\end{array}$ & 3 & \\
\cline { 1 - 2 } Intention to use (IU) & 2 & $\begin{array}{l}\text { DeLone and } \\
\text { Mclean [6] \& } \\
\text { Chen et al. [5] }\end{array}$ \\
\hline Total & 22 & \\
\hline
\end{tabular}

\section{RESULTS AND DISCUSSION}

\subsection{Demographics}

More than half of the survey $(61.3 \%)$ were women, and almost all respondents who filled out the questionnaire owned a laptop (92.7\%). Internet connection quality $59.1 \%$ of respondents sometimes good or bad or unstable, followed by good internet quality of $30.7 \%$ of respondents. The majority of respondents have the first experience doing online learning while at university (63.9\%). Regarding LMS management, participants thought that user convenience was the responsibility of the university $(70.4 \%)$. More details regarding the demographics of the respondents are presented in Table 2.

Table 2. Demographics of participant

\begin{tabular}{|l|l|l|l|}
\hline Profiles & Item & Q & $\%$ \\
\hline \multirow{2}{*}{ Sex } & Male & 106 & $38,7 \%$ \\
\cline { 2 - 4 } & Female & 168 & $61,3 \%$ \\
\hline \multirow{2}{*}{$\begin{array}{l}\text { Laptop/PC } \\
\text { owner }\end{array}$} & Yes & 254 & $92,7 \%$ \\
\cline { 2 - 4 } & No & 20 & $7,3 \%$ \\
\hline
\end{tabular}




\begin{tabular}{|l|l|l|l|}
\multirow{4}{*}{$\begin{array}{l}\text { Internet } \\
\text { Connection }\end{array}$} & Good & 84 & $30,7 \%$ \\
\cline { 2 - 4 } & Bad & 19 & $6,9 \%$ \\
\cline { 2 - 4 } & $\begin{array}{l}\text { Sometime } \\
\text { good or bad }\end{array}$ & 162 & $59,1 \%$ \\
\cline { 2 - 4 } & Very bad & 3 & $1,1 \%$ \\
\cline { 2 - 4 } & Very good & 6 & $2,2 \%$ \\
\hline $\begin{array}{l}\text { First time using } \\
\text { E-Learing }\end{array}$ & $\begin{array}{l}\text { Elementry } \\
\text { School }\end{array}$ & 7 & $2,6 \%$ \\
\cline { 2 - 4 } & $\begin{array}{l}\text { Junior High } \\
\text { School }\end{array}$ & 25 & $9,1 \%$ \\
\cline { 2 - 4 } & $\begin{array}{l}\text { Senior High } \\
\text { School }\end{array}$ & 67 & $24,5 \%$ \\
\cline { 2 - 4 } & University & 175 & $63,9 \%$ \\
\hline \multirow{2}{*}{$\begin{array}{l}\text { LMS } \\
\text { Resposibiliy } \\
\text { belongs to }\end{array}$} & $\begin{array}{l}\text { University } \\
\text { level }\end{array}$ & 193 & $70,4 \%$ \\
\cline { 2 - 4 } & Faculty level & 45 & $16,4 \%$ \\
\cline { 2 - 4 } & Lecturer & 36 & $13,1 \%$ \\
\hline
\end{tabular}

\subsection{Goodness of Fit Outer model (First)}

To test the goodness of fit outer model, researchers used the loading factor, cross-loading, composite reliability (table 3), and composite reliability and average variance extracted (AVE) (table 4). Based on the results of preliminary data processing, five indicators are candidates for elimination. Furthermore, referring to AVE, the variable learner interface (LI) has a value below 0.5 . Therefore, we omitted the smallest learner interface indicator (LI4).

Table 3. Loading factor, cross loading, composite reliability

\begin{tabular}{|l|r|r|l|}
\hline Indicators & $\begin{array}{l}\text { Loading } \\
\text { factor } \\
>0.5\end{array}$ & \multicolumn{2}{|c|}{$\begin{array}{r}\text { Crossloading } \\
\text { indicators value }\end{array}$} \\
\hline COM1 & 0,794 & 0,794 & Yes \\
\hline COM2 & 0,767 & 0,767 & Yes \\
\hline COM3 & 0,810 & 0,810 & Yes \\
\hline COM4 & 0,792 & 0,792 & Yes \\
\hline INT1 & 0,724 & 0,724 & Yes \\
\hline INT2 & 0,883 & 0,883 & Yes \\
\hline INT3 & 0,857 & 0,857 & Yes \\
\hline LI1 & $\mathbf{0 , 6 6 1}$ & 0,661 & Yes \\
\hline LI2 & 0,801 & 0,801 & Yes \\
\hline LI3 & 0,751 & 0,751 & Yes \\
\hline LI4 & $\mathbf{0 , 5 9 3}$ & 0,593 & Yes \\
\hline LI5 & $\mathbf{0 , 6 9 1}$ & 0,691 & Yes \\
\hline PER1 & $\mathbf{0 , 5 9 8}$ & 0,598 & Yes \\
\hline
\end{tabular}

\begin{tabular}{|l|l|l|l|} 
PER2 & $\mathbf{0 , 6 9 4}$ & 0,694 & Yes \\
\hline PER3 & 0,715 & 0,715 & Yes \\
\hline PER4 & 0,750 & 0,750 & Yes \\
\hline PER5 & 0,778 & 0,778 & Yes \\
\hline PER6 & 0,713 & 0,713 & Yes \\
\hline PER7 & 0,719 & 0,719 & Yes \\
\hline PER8 & 0,704 & 0,704 & Yes \\
\hline S1 & 0,943 & 0,943 & Yes \\
\hline S2 & 0,922 & 0,922 & Yes \\
\hline
\end{tabular}

Table 4. Composite reliability and average variance extracted (AVE)

\begin{tabular}{|l|r|r|}
\hline Variables & $\begin{array}{l}\text { Composite } \\
\text { reability }> \\
0.7\end{array}$ & $\begin{array}{l}\text { AVE }> \\
0.5\end{array}$ \\
\hline $\begin{array}{l}\text { Learning } \\
\text { Community }\end{array}$ & 0,863 & 0,626 \\
\hline Intention to use & 0,863 & 0,68 \\
\hline Learner interface & 0,863 & 0,495 \\
\hline Personalization & 0,89 & 0,505 \\
\hline Satisfaction & 0,93 & 0,87 \\
\hline
\end{tabular}

\subsection{Goodness of Fit Inner model (First)}

The goodness of Fit (GoF) inner model is done to see the fit between variables in a model offered. To test the GoF inner model, we used $\mathrm{R}$ square, $\mathrm{f}$ square, and Q square (Table 4).

Table 5. R square, f square, dan $\mathrm{Q}$ square

\begin{tabular}{|c|c|c|c|c|c|}
\hline \multicolumn{6}{|c|}{ R square } \\
\hline Variables & \multicolumn{2}{|c|}{ R Square } & \multicolumn{3}{|c|}{$\begin{array}{l}\text { R Square } \\
\text { Adjusted }\end{array}$} \\
\hline Intention to use & \multicolumn{2}{|c|}{0,540} & \multicolumn{3}{|c|}{0,537} \\
\hline Satisfaction & \multicolumn{2}{|c|}{0,584} & \multicolumn{3}{|c|}{0,583} \\
\hline \multicolumn{6}{|c|}{ F square } \\
\hline Variables & IU & LC & LI & $P$ & $\mathrm{~S}$ \\
\hline Intention to (IU) & & & & & 1,404 \\
\hline $\begin{array}{l}\text { Learning Community } \\
\text { (LC) }\end{array}$ & 0,013 & & & & \\
\hline Learning Interface (LI) & 0,050 & & & & \\
\hline Personalization $(\mathrm{P})$ & 0,282 & & & & \\
\hline \multicolumn{6}{|l|}{ Satisfaction (S) } \\
\hline \multicolumn{6}{|c|}{ Q square } \\
\hline Variables & \multicolumn{5}{|c|}{$\mathrm{Q}^{2}(=1-\mathrm{SSE} / \mathrm{SSO})$} \\
\hline
\end{tabular}




\begin{tabular}{|l|c|}
\cline { 2 - 2 } Intention to Use (IU) & 0,345 \\
\hline $\begin{array}{l}\text { Learning Community } \\
(\text { LC) }\end{array}$ & \\
\hline Learning Interface (LI) & \\
\hline Personalization (P) & \\
\hline Satisfaction (S) & 0,482 \\
\hline
\end{tabular}

Based on the GoF inner model test results, we find that the variable "learning community" has a very small value for "Intention to Use". A value of $\mathrm{F}^{2}$ less than 0.02 is categorized as a weak influence of predictor latent variables (exogenous latent variables) at the structural level. Therefore, in the next process, the 'learning community' variable will be removed, leaving 'learning interface', 'personalization', 'intention to use ', and' satisfaction '.

\subsection{Structural Equation Modeling}

Before performing structural equation modeling (SEM) analysis, we re-tested the goodness of fit for the proposed research framework. The second submission resulted in a good statistical value and was acceptable for further analysis.

The values examined in the SEM test are t-statistic (Figure 4), p-value, and original sample (o). The results of the three statistical values can be seen in Table 5 .

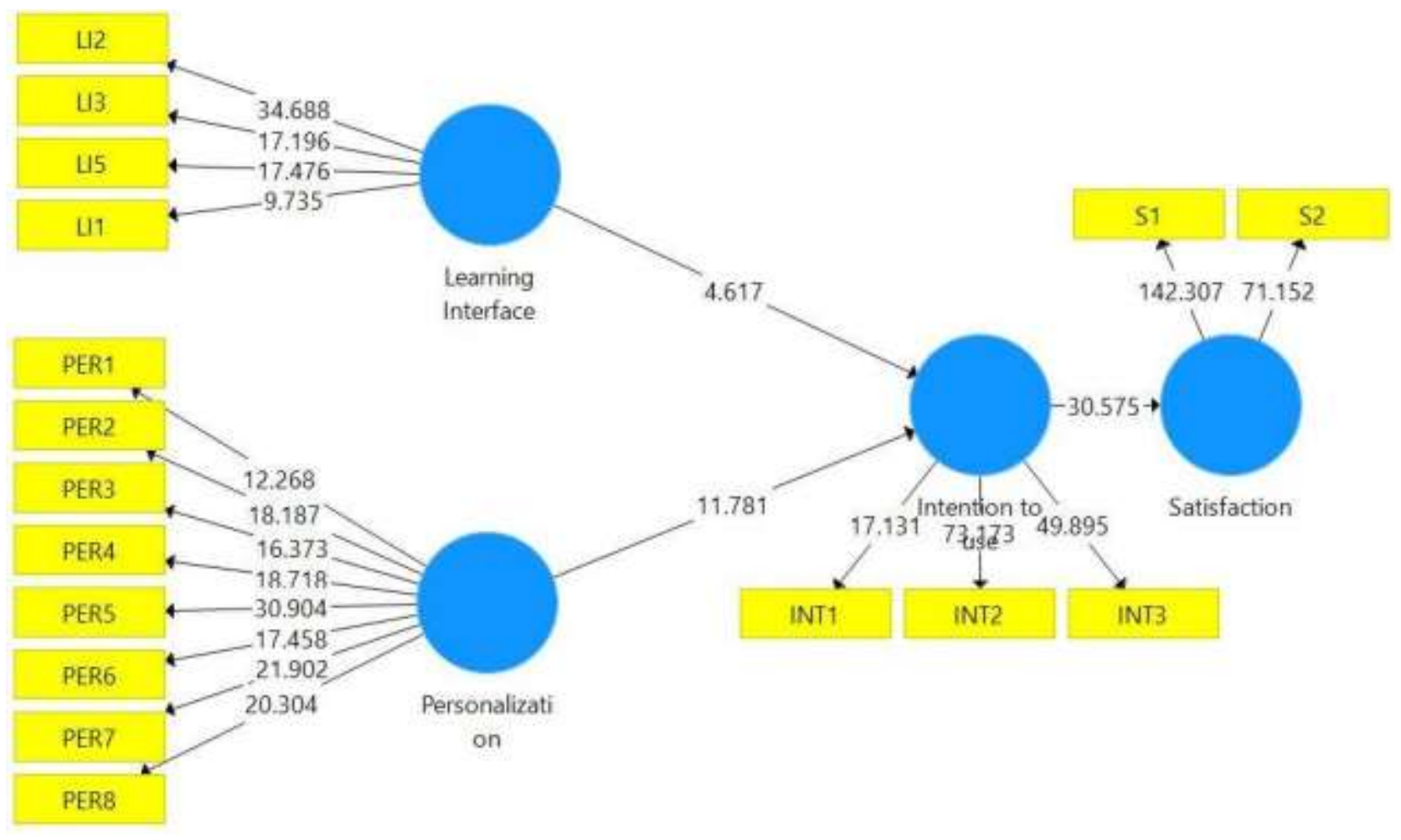

Figure 4 t-statistic value

Table 6. t-statistic, p-value, dan original sample

\begin{tabular}{|l|r|r|r|}
\hline Path & $\begin{array}{l}\text { Original } \\
\text { Sample } \\
(\mathrm{O})\end{array}$ & T Statistics & $\begin{array}{l}P \\
\text { Values }\end{array}$ \\
\hline $\begin{array}{l}\text { Learning } \\
\text { Interface -> } \\
\text { Intention to use }\end{array}$ & 0,237 & 4,617 & 0,000 \\
\hline $\begin{array}{l}\text { Personalization - } \\
>\text { Intention to } \\
\text { use }\end{array}$ & 0,570 & 11,781 & 0,000 \\
\hline
\end{tabular}

\begin{tabular}{|l|l|l|l|}
$\begin{array}{l}\text { Intention to use - } \\
\text { Satisfaction }\end{array}$ & 0,764 & 30,575 & 0,000 \\
\hline
\end{tabular}

Based on the SEM test, all the proposed hypotheses were accepted, except the $\mathrm{H} 2$ hypothesis which was cancelled because this variable was removed in the second stage analysis.

Learner interface is significantly related to intention to use $(\gamma=0.237, t=4.617)$. Therefore, $\mathrm{H} 1$ is accepted. These results are consistent with that of Wang [7] and Chen et.al [5]. This information reveals that the learner interface from the iLearn LMS has increased students' desire to adopt the LMS system. 
A learning community which was initially $\mathrm{H} 2$, could not be processed because the statistical values did not meet the standards $(\mathrm{F} 2=0.13)$. Therefore, $\mathrm{H} 2$ is irrelevant. This case is contrary to the results obtained by Chen et al. [5].

Furthermore, personalization has a significant relationship with intention to use $(\gamma=0.57, \mathrm{t}=11,781)$, so that $\mathrm{H} 3$ is accepted. These results are consistent with studies by Wang [7] and Chen et. [5]. Finally, the intention to use has a significant relationship with satisfaction $(\gamma=0.764, \mathrm{t}=30,575)$. Thus, it can be concluded that $\mathrm{H} 4$ is accepted. These results are consistent with the results of previous studies [6], where students have a level of satisfaction that is influenced by the desire to use the system. The higher the desire to use the LMS, the higher the user satisfaction.

\section{CONCLUSION}

Based on the results of this study, several conclusions can be drawn and their implications for the person in charge of LMS. First, the learner interface, an important variable to increase the desire to use an LMS. The beauty of the website or system is the key to this. University level ICT employees can increase user desires by always updating the university's LMS. For lecturers, it is hoped that the LMS content exposure will not be rigid so that it will attract students' interest to use it.

Second, personalization is needed by students to increase their desire to use LMS. Personalization is the system's ability to adapt its features to user needs. In the Moodle-based iLearn system, personalization can be done by arranging the order of the courses currently being taken.

Third, the learning community was found to be incompatible with this construct. This may be because students are not related to their colleagues in using LMS. Finally, students who have a high desire to use LMS have a high level of satisfaction. Therefore, academics need to cultivate the intention to use students so that the teaching-learning process is better.

\section{ACKNOWLEDGMENT}

This research was funded by a PPMP grant from LP3M Universitas Andalas 2020.

\section{REFERENCES}

[1] K. A. Al-Busaidi, "An empirical investigation linking learners' adoption of blended learning to their intention of full e-learning," Behav. Inf. Technol., vol. 32, no. 11, pp. 1168-1176, 2013.

[2] A. K. M. N. Islam, "Investigating e-learning system usage outcomes in the university context," Comput. Educ., vol. 69, pp. 387-399, 2013.

[3] A. K. M. N. Islam, "Understanding e-learning system users' post-adoption usage behavior and its outcomes: a study of a learning management system," Turku, 2012.

[4] A. K. M. N. Islam and N. Azad, "Satisfaction and continuance with a learning management system," Int. J. Inf. Learn. Technol., vol. 32, no. 2, pp. 109123, 2015.

[5] M. L. Chen, Z. Y. Su, T. Y. Wu, T. Y. Shieh, and C. H. Chiang, "Influence of dentistry students' eLearning satisfaction: A questionnaire survey," Journal of Medical Systems, vol. 35, no. 6. Springer, pp. 1595-1603, Dec-2011.

[6] E. R. DeLone, W. H., and McLean, "The DeLone and McLean model of information systems success: A ten-year update," J. Manag. Inf. Syst., vol. 19, no. 4, pp. 9-30, 2003.

[7] Y. S. Wang, "Assessment of learner satisfaction with asynchronous electronic learning systems," Inf. Manag., vol. 41, no. 1, pp. 75-86, 2003.

[8] G. Naveh, D. Tubin, and N. Pliskin, "Student LMS use and satisfaction in academic institutions: The organizational perspective," Internet High. Educ., vol. 13, no. 3, pp. 127-133, 2010.

[9] OECD, "E-learning in tertiary education, policy brief," 2005.

[10] J. A. Hawkins, B.L. \& Rudy, "Fiscal Year 2007 Summary report, EDUCAUSE core data service," 2009.

[11] F. S. Jones, S., Johnson-Yale, C., Millermaier, S., \& Perez, "Academic work, the Internet and U.S. college students," Internet High. Educ., vol. 11, no. 3, pp. 165-177, 2008.

[12] M. Blin, F., \& Munro, "Why hasn't technology disrupted academics' teaching practice? Understanding resistance to change through the lens of activity theory," Comput. Educ., vol. 50, pp. 475-490, 2008.

[13] A. Frank, M., \& Barzilai, "esigning course web sites for supporting lecture-based courses in higher education - Some pedagogical aspects," Int. J. Instr. Technol. Distance Learn., vol. 1, no. 2, 2004.

[14] C. J. Bonk, "The Perfect E-Storm: Emerging technologies, enormous learner demand, enhanced pedagogy, and erased budgets," 2004.

[15] N. Selwyn, "The use of computer technology in university teaching and learning: A critical 
perspective," J. Comput. Assist. Learn., vol. 23, pp. 83-94, 2007.

[16] F. D. Davis, "Perceived usefulness, perceived ease of use, and user acceptance of information technology," MIS Q. Manag. Inf. Syst., vol. 13, no. 3, pp. 319-339, 1989.

[17] P. R. Davis, F. D., Bagozzi, R. P., and Warshaw, "User acceptance of computer technology: A comparison of two theoretical models," Manage. Sci., vol. 35, no. 8, pp. 982-1003, 1989.

[18] F. D. Davis, R. P. Bagozzi, and P. R. Warshaw, "User Acceptance of Computer Technology: A Comparison of Two Theoretical Models," Manage. Sci., vol. 35, no. 8, pp. 982-1003, Aug. 1989. 